\title{
ANALISIS MUTU IMPLEMENTASI PENDIDIKAN GRATIS DI JABODETABEK
}

\author{
Asep Ediana Latip, Nafia Wafiqni \\ Fakultas Ilmu Tarbiyah dan Keguruan, UIN Syarif Hidayatullah Jakarta \\ Email: asep.ediana@uinjkt.ac.id, nafia.wafiqni@uinjkt.ac.id
}

Naskah diterima : 16 Februari 2017, direvisi : 22 Februari 2017, disetujui : 20 April 2017

\begin{abstract}
This study aimed to analyze the quality of the implementation of free education at the level of free education in Jabodetabek. Subjects were implementing elements of the free education that teachers and principals in the area of Jakarta, Bogor, Depok, Tangerang and Bekasi. This research is non-experimental research because no manipulation of study variables. The type of research is a survey method. This research data collection techniques are questionnaires and observation techniques. Questionnaires and observation selected in this study, because of the variables to be measured is certain, that the quality of the implementation of free education at the primary level. This technique is also an effective technique for measuring the purpose of this study of the respondents are already established. The research result shows that the implementation of free education in Jabodetabek meet the quality standards of education good views of inputs, processes, outputs, and outcomes of education. Judging from the quality standard based education accreditation, quality free education in Jabodetabek meet the quality standards of education with the acquisition value of $\mathrm{A}$. Model implementation of free education of the funding envisaged in three models of education, namely the liberation of all kinds of levies by schools to parents, Liberation operational cost of education to parents, except for expenses for personal needs such as school uniforms and operational financing of education imposed on BOS (School Operational Cost). Impact of free education based on the quality of the inputs, processes, outputs, and outcomes, as well as quality accreditation are also models of implementation of free education for the elderly, the implementation of free education in Jabodetabek with quality standards do not have the participation of parents is optimal, had the satisfaction of graduates, and assisted from the financing of education free of charge. For teachers based on the acquisition of data about the quality of free education, teachers meet standards with optimal learning process.
\end{abstract}

\section{Keywords: Quality Education, Free Education, Elementary Education}

Pengutipan: Latip, Asep Ediana., Wafiqni, Nafia. (2017). Analisis Mutu Implementasi Pendidikan Gratis di Jabodetabek. JMIE: Journal of Madrasah Ibtidaiyah Education, 1(1), 2017, 96-110. sd.v1i1.27. 


\section{Pendahuluan}

Menyelenggarakn pendidikan bermutu merupakan bentuk akuntabilitas institusi pendidikan sebagai quality assurance terhadap partisipasi masyarakat dalam mewujudkan outcome yang kompetitif. Pendidikan yang bermutu dapat terbangun apabila terselenggara secara teroganisir dan sistemik diantara berbagai komponen pendidikan.

Standar mutu yang dapat menjadi referensi nasional dapat merujuk pada hasil akreditasi pendidikan. Akreditasi pendidikan merupakan lembaga independen yang diselenggarakan oleh Badan Akreditasi Sekolah/Perguruan Tinggi. Proses akreditasi tidak mensyaratkan proses pendidikan dilaksanakan gratis atau berbayar, yang penting adalah memenuhi standar yang dipersyaratkan dalam proses akreditasi termasuk didalmanya adalah proses pembelajaran. Dengan demikian, pendidikan gratis sejatinya dapat dilaksanakan dengan proses yang bermutu pula baik merujuk pada hasil akreditasi, input, proses, output maupun outcome pendidikan.

Namun, permasalahan pendidikan gratis ternyata tidak sekadar persoalan rendahnya mutu pembelajaran tetapi disisi lain adalah implementasi pendidikan gratis belum berhasil mengurangi angkat buta huruf dan belum menambah angka partisipasi masyarakat terhadap prsoes pendidikan, padahal seharusnya pendidikan gratis dapat mendongkrak angka partisipasi masayarakat terhadap pendidikan. Namun, tentu saja hal ini mengundang tanya mengapa sekolah gratis tidak banyak diminati oleh masyarakat? bagaimana mutu pelaksanaan sekolah gratis? hal ini penting untuk dikaji dan secara kolektif semua berkeyakinan bahwa asumsi gratis selalu relevan dengan mutu pelaksanaan pembelajaran yang rendah sehingga ada adagium sekolah mahal saja sudah rendah mutu pelaksanaannya apalagi sekolah yang gratis. Oleh karena itu penelitian ini dalam rangka menjaring data secara faktual terkait mutu implementasi pendidikan gratis pada tingkat pendidikan dasar sehingga penelitian ini tentu saja bermanfaat untuk mengkontrol dan mengevaluasi proses pelaksanaan pendidikan gratis dan menjadi data empiris untuk bahan peningkatan mutu pelaksanaan pendidikan gratis. Penelitian ini akan menjawab opini asumtif dengan buktik empirik melalui proses penelitian yang menjaminkan pada hasil akreditasi, input, proses, output dan outcome pendidikan.

\section{Hasil dan Pembahasan}

\section{Mutu pendidikan gratis di Jabodetabek}

Upaya meningkatkan mutu pendidikan gratis yang memenuhi standar ideal maupun standar nasional, sejatinya terus digalakkan dalam rangka optimalisasi mutu pendidikan yang apapun pembiayaannya gratis ataupun tidak gratis. Upaya peningkatan mutu pendidikan gratis ideal diantaranya yang diidealkan Gaspers dengan memenuhi kriteria performance, reliability, dan memehuhi kebutuhan masyarakat, dan seperti yang diidealkan Gordon and Partington, Murgatroyd and Morgan dan The World Bank bahwa kriteria pendidikan bermutu yang ideal adalah 
memenuhi kriteria yang berkaitan dengan lulusan (sudents outcome), lingkungan belajar (the learning environment), kualitas standar (quality requirements) dan pencapaian tujuan belajar (learning goals) dan kesesuaian standar akademik (academic standards).

Dapat juga memperhatikan mutu pendidikan yang diidealkan oleh Deming bahwa mutu pendidikan akan selalu harus memenuhi standar planning, doing, checking, dan acting. Atau yang disandarkan secara nasional bahwa mutu pendidikan sejatinya memehunuhi kerangka mutu nasional yang meliputi input, proses. Output, dan outcome. Sehingga dari kerangka ideal di atas, mutu pendidikan gratis dalam peneilitian ini menggunakan frame work mutu input, proses, output, dan outcome.

Berdasarkan hasil penelitian dapat dijelaskan bahwa mutu pendidikan gratis di Jakarta, Bogor, Depok, Tangerang dan Bekasi dapat memenuhi kriteria ideal dalam kerangka input, proses, output dan outcome dengan standar skor mutu 83 yang berarti memenuhi implementasi mutu pendidikan gratis yang baik. Dengan kriteria yang baik ini, mutu pendidikan gratis akuntabel secara publik untuk tetap dijadikan sebagai referensi perwujudan peserta didik yang sesuai dengan fungsi dan tujuan pendidikan nasional yang diamanakan Undang-Undang No 20 tahun 2013 tentang Sistem Pendidikan Nasional bahwa peserta didik hendaknya dapat menjadi peserta didik yang beriman dan bertakwa, kreatif dan bertanggungjawab.

Standar mutu pendidikan ideal berbasis yuridis formal yang sesuai dalam kerangka input pendidikan yang memenuhi criteria kesiapan guru dan peserta didik dalam menjalankan proses pendidikan atau berproses. Kesiapan guru dan peserta didik mengembangkan perencanaan pendidikan yang bemutu, dan perencanaan strategis dalam menjalankan proses pendidikan. Melaksanakan seleksi masuk dengan ketat dan dapat dipertanggungjawabkan bedasarkan prestasi akademik sebagai diagnosis dan placement prestasi peserta didik. melakukan psikotes terhadap peserta didik untuk mengidentifikasi karakteristiknya baik dari intelektual, social, moral, dan emosional serta mengenal gaya belajar untuk memberikan scaffolding dan treatment terhadap peserta didik melalui proses pendidikan, dan tes fisik dilakukan dalam menjaga mutu input pendidikan gratis peserta didik sehingga perta didik memiliki kesiapan fisik dalam melaksanakan pendidikan.

Dinamis terhadap perubahan sebagai paradima pendidikan gratis yang dikembangkan guru dan kepala sekolah dalam menjalankan pendidikannya menjadi pembuka optimalisasi mutu implementasi pendidikan gratis. Guru yang open minded dengan perubahan guru dipastikan memiliki motivasi untuk melaksanakan pendidikan secara inovatif, kreatif, menantang dan menyenangkan. Kepala sekolah yang mimiliki will untuk kemajuan pendidikan gratis dipastikan dapat dengan mudah menemukan berbagai alternative penyeselaian masalah pendidikan dan yang pasti memfasilitasi proses pendidikan yang berkualitas.

Responsif terhadap pembaharuan sebagai asas pengembangan diri baik dalam optimalisasi pengetahuan dan wawasan yang dimiliki dapat menjalankan 
proses pendidikan gratis yang suistainble dengan kebutuhan peserta didik. Peserta didik yang hidup diera digtal menjadi keharusan bahwa guru semestinya memfasilitasi proses pembelajaran yang berkualitas. Kondisi ideal di atas adalah dapat terekam dalam penelitian yang terdapat diwilayah Jabodetabek bahwa mutu input pendidikan gratis di Jabodetabek. Di Jakarta, dari tiga sekolah yang menjadi sasaran penelitian ini yang terdiri dari MIN Nurul Iman, SDN Jatinegara Kaum 01, dan SDN Jatinegara Kaum 03, serta terdiri dari 21 orang yang didalamnya ada kepala sekolah dan guru, bahwa input pendidikan gratis di Jakarta adalah $58 \%$ bermutu. Di Bogor, dari tiga sekolah yang terdiri dari SDN Jampang, 01,02 dan 03, serta terdiri dari 21 orang yang didalamnya ada kepala sekolah dan guru, bahwa input pendidikan gratis di Bogor 64 \% bermutu. Di Depok, dari tiga sekolah yang terdiri dari SDN Tugu 5, SDN Tugu 1 dan SDN Pasing Gunung Selatan 1 serta terdiri dari 21 orang yang didalamnya terdapat kepala sekolah dan guru, bahwa input pendidikan gratis di Depok 68 \% bermutu. Di Tanggerang, dari tiga sekolah yang terdiri dari SDN Ciputat 1 Ciputat, SDN Ciputat VI dan SDN Sawah 02, serta terdiri dari 21 orang yang didalamnya terdapat kepala sekolah dan guru, bahwa input pendidikan gratis di Tanggerang $63 \%$ bermutu. Di Bekasi, dari tiga sekolah yang menjadi sasaran penelitian ini terdiri dari SDN Bekasi Jaya VIII, SDN Bekasi Jaya XIV dan SDN Jati Waringin IX, serta terdiri dari 21 orang yang didalamnya terdapat kepala sekolah dan guru, bahwa input pendidikan gratis $56 \%$ bermutu.

Sebagaimana diketahui bahwa mutu input pendidikan gratis terdiri dari melakukan seleksi masuk sebagai peserta didik berdasarkan prestasi akademik, melakukan seleksi masuk sebagai peserta didik dengan psikotes, mengembangan pembinaan keterampilan akademik dan non akademik bagi siswa, melakukan seleksi sebagai guru bedasarkan prestasi akademik, melakukan seleksi sebagai guru berdasarkan prestasi non akademik, melakukan selesksi sebagai guru yang dapat dipertanggungjawabkan secara profesional, melakukan pelatihan untuk pengembangan kompetensi guru. Namun dari perolehan hasil penelitian didapat bahwa mutu input pendidikan gratis memperoleh skor rata 62 artinya implementasi pendidikan gratis di Jakarta, Bogor, Depok dan Tangerang kurang memenuhi kriteria ideal mutu input pendidikan gratis, dan perlu untuk digenjot dengan dengan merefleksi pemenuhan standar ideal mutu input pendidikan gratis.

Mutu output pendidikan memenuhi kirteria suasana kelas Pakem Bermakna, kesiapan dan motivasi belajar, kemampuan profesional, moral kerja (kemampuan personal), relevansi konten dan operasionalisasi proses pembelajaran, kecukupan dan kefektifan dalam mendukung proses pembelajaran, proses menghasilkan output dan outcome (proses pembelajaran), terpenuhi dan kondusif bagi proses pembelajaran, mendukung untuk kegiatan belajar, profesionalimse tinggi, dan kesejateraan yang memadai, improvisasi kurikulum sehingga memenuhi kebutuhan siswa yang pada umumnya memiliki motivasi belajar yang tinggi dibandingkan dengan siswa seusianya, guru melaksanakan tugas individu dan kelompok, proses 
pembelajaran memanfaatkan dan merefleksikan lingkungan sekitar.

Kondisi di atas tergambar dalam hasil penelitian ini bahwa mutu proses pendidikan gratis se Jabodetabek. Di Jakarta, dari tiga sekolah yang menjadi sasaran penelitian ini yang terdiri dari MIN Nurul Iman, SDN Jatinegara Kaum 01, dan SDN Jatinegara Kaum 03, serta terdiri dari 21 orang yang didalamnya ada kepala sekolah dan guru, bahwa proses pendidikan gratis di Jakarta adalah $91 \%$ bermutu. Di Bogor, dari tiga sekolah yang terdiri dari SDN Jampang, 01,02 dan 03, serta terdiri dari 21 orang yang didalamnya ada kepala sekolah dan guru, bahwa proses pendidikan gratis di Bogor $90 \%$ bermutu. Di Depok, dari tiga sekolah yang terdiri dari SDN Tugu 5, SDN Tugu 1 dan SDN Pasing Gunung Selatan 1 serta terdiri dari 21 orang yang didalamnya terdapat kepala sekolah dan guru, bahwa proses pendidikan gratis di Depok $80 \%$ bermutu. Untuk wilayah Tanggerang, dari tiga sekolah yang terdiri dari SDN Ciputat 1 Ciputat, SDN Ciputat VI dan SDN Sawah 02, serta terdiri dari 21 orang yang didalamnya terdapat kepala sekolah dan guru, bahwa proses pendidikan gratis di Tanggerang $88 \%$ bermutu. Di Bekasi, dari tiga sekolah yang menjadi sasaran penelitian ini terdiri dari SDN Bekasi Jaya VIII, SDN Bekasi Jaya XIV dan SDN Jati Waringin IX, serta terdiri dari 21 orang yang didalamnya terdapat kepala sekolah dan guru, bahwa proses pendidikan gratis 92 $\%$ bermutu.

Standar mutu proses adalah memperhatikan sikap dan tempat duduk peserta didik, memulai pembelajaran setelah peserta didik siap untuk belajar, melakukan appersepsi (mengkaitkan materi yang disajikan dengan materi yang telah dipelajari sehingga terjadi kesinambungan), memberikan motivasi untuk selalu terus belajar kepada peserta didik, melakukan proses pembelajaran aktif, kreatif, efektif, menyenangkan dan bermakna bersama peserta didik, menciptakan proses pembelajaran kondusif dengan menanggapi dan merespon pertanyaan peserta didik dengan antusias, menjelaskan pentingnya materi ajar yang akan dipelajari peserat didik, memberi kesempatan untuk bertanya dan menjawab pertanyaan kepada peserta didik, menggunakan media dalam mendukung proses pembelajaran yang efektif, mengembangkan bahan ajar pembelajaran yang relevan dengan kurikulum yang berlaku, melaksankan pembelajaran secara individu dan kelompok dengan variatif, memanfaatkan lingkungan sekitar sebagai sumber belajar bagi peserta didik, melaksanakan pembelajaran yang dinamis dan mendorong peserta didik untuk inovatif, menciptakan iklim dan suasana kelas yang mendukung untuk belajar, melakukan evaluasi pembelajaran yang komprehensif terhadap peserta didik. Adapun taraf mutu proses pendidikan gratis di Jakarta, Bogor, Depok, Tangerang dan Bekasi bernilai 89, artinya mutu proses pendidikan gratis di Jabodetabek memenuhi kriteria yang baik, jadi implementasi pendidikan gratis telah bermutu baik dalam menjalankan proses pendidikan yang dilakukan oleh pendidik.

Mutu output pendidikan gratis se Jabodetabek diperoleh hasil penelitian 
adalah untuk wilayah Jakarta, dari tiga sekolah yang menjadi sasaran penelitian ini yang terdiri dari MIN Nurul Iman, SDN Jatinegara Kaum 01, dan SDN Jatinegara Kaum 03, serta terdiri dari 21 orang yang didalamnya ada kepala sekolah dan guru, bahwa output pendidikan gratis di Jakarta adalah $61 \%$ bermutu. Untuk wilayah Bogor, dari tiga sekolah yang terdiri dari SDN Jampang, 01,02 dan 03, serta terdiri dari 21 orang yang didalamnya ada kepala sekolah dan guru, bahwa output pendidikan gratis di Bogor $66 \%$ bermutu. Untuk wilayah Depok, dari tiga sekolah yang terdiri dari SDN Tugu 5, SDN Tugu 1 dan SDN Pasing Gunung Selatan 1 serta terdiri dari 21 orang yang didalamnya terdapat kepala sekolah dan guru, bahwa output pendidikan gratis di Depok $68 \%$ bermutu. Untuk wilayah Tanggerang, dari tiga sekolah yang terdiri dari SDN Ciputat 1 Ciputat, SDN Ciputat VI dan SDN Sawah 02, serta terdiri dari 21 orang yang didalamnya terdapat kepala sekolah dan guru, bahwa output pendidikan gratis di Tanggerang $72 \%$ bermutu. Untuk wilayah Bekasi, dari tiga sekolah yang menjadi sasaran penelitian ini terdiri dari SDN Bekasi Jaya VIII, SDN Bekasi Jaya XIV dan SDN Jati Waringin IX, serta terdiri dari 21 orang yang didalamnya terdapat kepala sekolah dan guru, bahwa output pendidikan gratis $68 \%$ bermutu.

Adapun kirteria mutu otuput penelitian ini adalah peserta didik memiliki kualitas hasil belajar akademik yang tinggi, peserta didik memiliki prestasi non akademik yang yang dapat dipertanggungjawabkan, peserta didik memiliki prestasi akademik pada tingkat regional, peserta didik memiliki prestasi akademik pada tingkat nasional, peserta didik memiliki prestasi akademik pada tingkat lokal, guru memiliki prestasi keraj yang berkualitas dan dapat dipertanggungjawabkan, peserta didik memiliki prestasi non akademik pada tingkat regional, peserta didik memiliki prestasi non akademik pada tingkat nasional, peserta didik memiliki prestasi non akademik pada tingkat lokal, peserta didik memiliki karakter kebangsaan yang dibanggakan (jujur, disiplin, tanggungjawab dan percaya diri) peserta didik memiliki motivasi pencapaian prestasi akadmeik yang tinggi dalam pembelajaran. Sehingga mutu output pendidikan gratis di Jakarta, Bogor, Depok, Bekasi, dan Tangerang memenuhi taraf kriteria mutu pendidikan gratis rata-rata 67, artinya mutu output implementasi pendidikan gratis di Jabodetabek bermutu rendah untuk memenuhi standar ideal mutu output pendidikan gratis baik teoritik maupun yuridis formal.

Implementasi mutu outcome pendidikan gratis diklasifikasi dengan memehuni criteria lulusan yang cepat terserap dunia kerja, mendapatkan gaji wajar, memiliki pengakuan kehebatan lulusan, dan orang tua merasa puas, pengguna lulusan yang merasa puas, sampai pada perguruan tinggi, dan disamping itu mendorong partisipasinya dalam pengembangan program-program pendidikan sekolah. Pihak sekolah memiliki standar promosi untuk pemasaran lulusan, penerimaan pengguna lulusan, dan kualitas pengguna, unggul dan bemanfaat bagi lingkungannya, partisipasi yang tinggi dalam proses pembelajaran dan kepuasan wali murid.

Kondisi ideal diatas tergambar dalam penelitian bahwa mutu outcome 
pendidikan gratis se Jabodetabek. Di Jakarta, dari tiga sekolah yang menjadi sasaran penelitian ini yang terdiri dari MIN Nurul Iman, SDN Jatinegara Kaum 01, dan SDN Jatinegara Kaum 03, serta terdiri dari 21 orang yang didalamnya ada kepala sekolah dan guru, bahwa outcome pendidikan gratis di Jakarta adalah $80 \%$ bermutu. Di Bogor, dari tiga sekolah yang terdiri dari SDN Jampang, 01,02 dan 03, serta terdiri dari 21 orang yang didalamnya ada kepala sekolah dan guru, bahwa outcome pendidikan gratis di Bogor $90 \%$ bermutu. Untuk wilayah Depok, dari tiga sekolah yang terdiri dari SDN Tugu 5, SDN Tugu 1 dan SDN Pasing Gunung Selatan 1 serta terdiri dari 21 orang yang didalamnya terdapat kepala sekolah dan guru, bahwa outcome pendidikan gratis di Depok $81 \%$ bermutu. Di Tanggerang, dari tiga sekolah yang terdiri dari SDN Ciputat 1 Ciputat, SDN Ciputat VI dan SDN Sawah 02, serta terdiri dari 21 orang yang didalamnya terdapat kepala sekolah dan guru, bahwa outcome pendidikan gratis di Tanggerang $82 \%$ bermutu. Di Bekasi, dari tiga sekolah yang menjadi sasaran penelitian ini terdiri dari SDN Bekasi Jaya VIII, SDN Bekasi Jaya XIV dan SDN Jati Waringin IX, serta terdiri dari 21 orang yang didalamnya terdapat kepala sekolah dan guru, bahwa outcome pendidikan gratis $85 \%$ bermutu.

Adapun kriteria ideal mutu outcome pendidikan gratis yang dimaksud adalah lulusannya terserap di sekolah/madrasah unggulan, pengakuan orang tua merasa bangga terhadap lulusannya, orang tua siswa berpartisipasi dalam pengembangan program akademik dan non akademik sekolah, pengakuan sekolah/madrasah jenjang selanjutnya merasa puas terhadap lulusannya, banyak orang tua beminat memilih sekolah/madrasah ini untuk anaknya, lulusannya memiliki kualitas akademik/non akademik yang dibanggakan orang tua, sekolah/madrasanya memiliki keunggulan dan bermanfaat bagi lingkungan sekitarnya. Dengan kriteria di atas, diketahui bahwa mutu outcome pendidikan gratis di Jakarta, Bogor, Depok, Tangerang dan Bekasi memperoleh taraf mutu dengan nilai 81, artinya implementasi pendidikan gratis di Jabodetabek memenuhi kriteria bermutu baik secara outcome.

Dari perolehan hasil penelitian tentang mutu pendidikan gratis tidak hanya dilihatdaristandar mutu pendidikan gratisideal dan formal, tetapi juga menggunakan salah satu alat penjamintan mutu yang digunakan oleh Badan Akreditasi Sekolah/ Madrasah yaitu akreditas yang merujuk pada Peraturan Pemerintah Nomor 19 Tahun 2005 tentang Standar Nasional Pendidikan sebagaimana telah diubah dengan Peraturan Pemerintah Nomor 32 Tahun 2013 tentang Perubahan atas Peraturan Pemerintah Nomor 19 tahun 2005 tentang Standar Nasional Pendidikan pasal 2 ayat (2) menyatakan bahwa penjaminan dan pengendalian mutu pendidikan yang sesuai dengan Standar Nasional Pendidikan (SNP) perlu dilakukan dalam tiga program terintegrasi, yaitu evaluasi, akreditasi, dan sertifikasi. Penjaminan mutu pendidikan ini bertujuan untuk memenuhi atau melampaui Standar Nasional Pendidikan. Adapun standar nasional pendidikan terdiri dari 8 standar nasional 
pendidikan yaitu

1. Standar Kompetensi Lulusan

2. Standar Isi

3. Standar Proses

4. Standar Pendidikan dan Tenaga Kependidikan

5. Standar Sarana dan Prasarana

6. Standar Pengelolaan

7. Standar Pembiayaan Pendidikan

8. Standar Penilaian Pendidikan

Hasil secara umum nilai akreditas sekolah madrasah di Jabodetabek adalah A, artinya memenuhi kriteria pendidikan gratis yang sangat bermutu, artinya memenuhi standar formal seperti yang dijelaskan dalam panduan akreditasi Sekolah/madrasah yang memiliki kriteria sebagai berikut:

1) memiliki surat keputusan pendirian/operasional sekolah/madrasah;

2) memiliki peserta didik pada semua tingkatan kelas;

3) memiliki sarana dan prasarana pendidikan;

4) memiliki pendidik dan tenaga kependidikan;

5) melaksanakan kurikulum yang berlaku; dan

6) telah menamatkan peserta didik.

Dengan demikian bahwa sekolah/madrasah yang menjadi sasaran dalam penelitian telah memenuhi kriteria penjaminan mutu pendidikan gratis di Jabodetabek. Untuk wilayah Jakarta, dari tiga sekolah yang menjadi sasaran penelitian ini yang terdiri dari MIN Nurul Iman, SDN Jatinegara Kaum 01, dan SDN Jatinegara Kaum 03, serta terdiri dari 21 orang yang didalamnya ada kepala sekolah dan guru, bahwa pendidikan gratis di Jakarta adalah $83 \%$ terakreditasi A dan B. Untuk wilayah Bogor, dari tiga sekolah yang terdiri dari SDN Jampang, 01,02 dan 03, serta terdiri dari 21 orang yang didalamnya ada kepala sekolah dan guru, bahwa pendidikan gratis di Bogor $33 \%$ terakreditasi B. Untuk wilayah Depok, dari tiga sekolah yang terdiri dari SDN Tugu 5, SDN Tugu 1 dan SDN Pasing Gunung Selatan 1 serta terdiri dari 21 orang yang didalamnya terdapat kepala sekolah dan guru, bahwa pendidikan gratis di Depok $83 \%$ terakreditasi A dan B. Untuk wilayah Tanggerang, dari tiga sekolah yang terdiri dari SDN Ciputat 1 Ciputat, SDN Ciputat VI dan SDN Sawah 02, serta terdiri dari 21 orang yang didalamnya terdapat kepala sekolah dan guru, bahwa pendidikan gratis di Tanggerang $100 \%$ terakreditas A. Untuk wilayah Bekasi, dari tiga sekolah yang menjadi sasaran penelitian ini terdiri dari SDN Bekasi Jaya VIII, SDN Bekasi Jaya XIV dan SDN Jati Waringin IX, serta terdiri dari 21 orang yang didalamnya terdapat kepala sekolah dan guru, bahwa pendidikan gratis $83 \%$ terakreditasi A dan B. 


\section{Model implementasi pendidikan gratis di Jabodetabek}

Sebagaimana diketahui bahwa pendidikan gratis adalah program yang dicanangkan oleh Pemerintah sebagai tindak lanjut dari amanat Undang-Undang Dasar (UUD) 1945 dimana dalam pasal 31 disebutkan bahwa tiap-tiap warga negara berhak mendapat pengajaran, pemerintah mengusahakan dan menyelenggarakan satu sistem pengajaran nasional, yang diatur dengan undang-undang. Pasal 31 Undang-Undang (UU) No. 20 Tahun 2003 kemudian menegaskan bahwa setiap warga negara yang berusia 6 tahun dapat mengikuti program wajib belajar, pemerintah dan pemerintah daerah menjamin terselenggaranya wajib belajar minimal pada jenjang pendidikan dasar tanpa memungut biaya.

Menjelaskan perundang-undangan di atas, Syamsiah, (2009) memberikan makna terhadap pendidikan gratis, bahwa pendidikan gratis adalah penyelenggaraan pendidikan tanpa mengikutsertakan masyarakat (orang tua) dalam pembiayaan, khususnya untuk keperluan operasional sekolah. Dalam pengertian seperti itu, konsekuensi kebijakan pendidikan gratis sangat bergantung pada perhitungan tentang biaya satuan (unit cost) di sekolah. Biaya satuan memberikan gambaran berapa sebenarnya rata-rata biaya yang diperlukan oleh sekolah untuk melayani satu murid.

Sebagaimana penelitian ini, diperoleh data bahwa implementasi pendidikan gratis di Jabodetabek. Untuk wilayah Jakarta, dari tiga sekolah yang menjadi sasaran penelitian ini yang terdiri dari MIN Nurul Iman, SDN Jatinegara Kaum 01, dan SDN Jatinegara Kaum 03, serta terdiri dari 21 orang yang didalamnya ada kepala sekolah dan guru, menginformasikan bahwa $73 \%$ mengimplementasikan pendidikan gratis. Untuk wilayah Bogor, dari tiga sekolah yang terdiri dari SDN Jampang, 01,02 dan 03, serta terdiri dari 21 orang yang didalamnya ada kepala sekolah dan guru, menginformasikan bahwa $58 \%$ mengimplementasikan pendidikan gratis. Untuk wilayah Depok, dari tiga sekolah yang terdiri dari SDN Tugu 5, SDN Tugu 1 dan SDN Pasing Gunung Selatan 1 serta terdiri dari 21 orang yang didalamnya terdapat kepala sekolah dan guru, menginformasikan bahwa $47 \%$ mengimplementasikan pendidikan gratis. Untuk wilayah Tanggerang, dari tiga sekolah yang terdiri dari SDN Ciputat 1 Ciputat, SDN Ciputat VI dan SDN Sawah 02, serta terdiri dari 21 orang yang didalamnya terdapat kepala sekolah dan guru, menginformasikan bahwa $83 \%$ mengimplementasikan pendidikan gratis. Untuk wilayah Bekasi, dari tiga sekolah yang menjadi sasaran penelitian ini terdiri dari SDN Bekasi Jaya VIII, SDN Bekasi Jaya XIV dan SDN Jati Waringin IX, serta terdiri dari 21 orang yang didalamnya terdapat kepala sekolah dan guru, menginformasikan bahwa $78 \%$ mengimplementasikan pendidikan gratis.

Adapun dilihat dari modelnya, implementasi pendidikan gratis berdasarkan sumber pembiayaannya adalah terdapat tiga model secara faktual yaitu:

a. Model Pembebasan segala jenis pungutan oleh sekolah terhadap orang tua 
b. Model Pembebasan biaya operasional pendidikan terhadap orang tua kecuali biaya untuk kebutuhan pribadi seperti seragam sekolah

c. Model Pembiayaan operasional pendidikan dibebankan pada dana BOS (Biaya Operasional Sekolah)

Komponen pembiayaan untuk seluruh kegiatan operasional terdiri dari 13 komponen.

Dana BOS yang diterima oleh sekolah, dapat digunakan untuk membiayai komponen kegiatan-kegiatan sekolah tersebut dengan penjelasan pada beberapa item komponen maupun item pembiayaan penggunaan Dana BOS tahun anggaran 2015, sebagai berikut berikut:

1. Pengembangan perpustakaan

2. Kegiatan dalam rangka penerimaan peserta didik baru

3. Kegiatan pembelajaran dan ekstra kurikuler peserta didik :

4. Kegiatan Ulangan dan Ujian

5. Pembelian bahan-bahan habis pakai

6. Langganan daya dan jasa

7. Perawatan sekolah/rehab ringan dan sanitasi sekolah

8. Pembayaran honorarium bulanan guru honorer dan tenaga kependidikan honorer

9. Pengembangan profesi guru

10. Membantu peserta didik miskin yang belum menerima bantuan program lain seperti KIP 2015

11. Pembiayaan pengelolaan BOS

12. Pembelian dan perawatan perangkat komputer:

13. Biaya lainnya jika seluruh komponen 1 s.d 12 telah terpenuhi pendanaannya dari BOS

Berdasarkan hasil penelitian bahwa model implementasi pendidikan gratis di atas dapat diketahui bahwa $41 \%$ mengimplementasikan pendidikan gratis di Jabodetabek dengan Pembebasan segala jenis pungutan oleh sekolah terhadap orang tua, $80 \%$ mengimplementasikan pendidikan gratis di Jabodetabek dengan Pembebasan biaya operasional pendidikan terhadap orang tua kecuali biaya untuk kebutuhan pribadi seperti seragam sekolah, dan $73 \%$ mengimplementasikan pendidikan gratis di Jabodetabek pembiayaan operasional pendidikan dibebankan pada dana BOS (Biaya Operasional Sekolah). Berkenaan dengan model implementasi pendidikan gratis dalam penelitian yang dilakukan oleh Nur Berlian VA. Bahwa Model Pelaksanaan Pendidikan Gratis di Kabupaten/Kota dan Dampaknya di Tingkat Sekolah dan Orang tua oleh temuannya: I) terdapat dua model pelaksanaan pendidikan "gratis", yaitu pembebasan dan pelarangan segala jenis pungutan oleh sekolah terhadap orangtua, dan subsidi biaya pendidikan 
dari pemerintah untuk meringankan beban orangtua, 2) tidak semua kabupaten/ kota memiliki \&tsar hukum yang kuat dalam melaksanakan program pendidikan "gratis"; 3) program pendidikan "gratis" cukup berpengaruh terhadap aspek pembelajaran dan manajemen sekolah, dan 4) pendidikan "gratis" berdampak positif dalam meringankan biaya pendidikan dan meningkatkan aktivitas belajar anak di sekolah dan di rumah.

\section{Dampak implementasi pendidikan gratis di Jabodetabek}

Dalam penelitian Model Pelaksanaan Pendidikan Gratis di Kabupaten/ Kota dan Dampaknya di Tingkat Sekolah dan Orang tua oleh Nur Berlian VA. Menjelaskan bahwa diantara temuananya adalah bahwa pendidikan "gratis" berdampak positif dalam meringankan biaya pendidikan dan meningkatkan aktivitas belajar anak di sekolah dan di rumah.

Dampak yang terjadi dalam penelitian tersebut, pada penelitian ini diajdikan sebagai salah satu aspek yang diteliti. Adapun dampak pada aspek tersebut adalah dampak pada aspek aktivitas pembelajaran, dan dampak pada partisipasi orang tua,.

a. dampak aktivitas pembelajaran aktivitas pembelajaran yang diharapkan adalah memenuhi kriteria sebagai berikut:

1. Konsetrasi dalam belajar

2. Peserta didik bersiap belajar

3. Menjawab pertanyaan guru tentang materi sebelumnya dan pengalamannya

4. Peserta didik giat belajar

5. Peserta didik melakukan pembelajaran dengan aktif, kreatif, efektif, dan menyenangkan

6. Peserta didik menanggapi dan merespon pertanyaan guru dengan antusias

7. Peserta didik menyimak dengan penjelasan guru

8. Peserta didik aktif bertanya pada setiap masalah yang belum difahami

9. Peserta aktif diskusi mempelajari bahan ajar yang disiapkan oleh guru

10. Peserta didik aktif kerja kelompok

11. Peserta didik aktif belajar dengan memanfaatkan lingkungan sekitar sebagai sumber belajar

12. Peserta didik belajar dapat menginovasi penugasan produk dari guru

13. Peserta didik belajar dalam suasana kelas yang mendukung untuk belajar

14. Peserta didik melaksanakan valuasi pembelajaran yang telah disiapkan guru

Berdasarkan karakteristik tersebut, kegiatan pembelajaran di sekolah/madrasah dengan program pendidikan gratis diperoleh hasil penelitian yang menggambarkan 
rata-rata nilai perolehan kegiatan pembelajaran di Jabodetabek. Di Jakarta, dari tiga sekolah yang menjadi sasaran penelitian ini yang terdiri dari MIN, dan dua SDN, serta terdiri dari 18 orang guru, memperoleh rata-rata nilai 68. Di Bogor, dari tiga sekolah yang terdiri dari SDN 01,02 dan 03, serta terdiri dari 18 orang guru, memperoleh rata-rata nilai 67 dalam melaksanakan kegiatan pembelajaran. Di Depok, dari tiga sekolah yang terdiri dari SDN 5, dua SDN 1 serta terdiri dari 18 orang guru, memeperoleh rata-rata nilai 65 dalam melaksanakan aktivitas pembelajaran. Di Tanggerang, dari tiga sekolah yang terdiri dari SDN 1, SDN VI dan SDN 02, serta terdiri dari 18 orang guru, memperoleh rata-rata nilai 67 dalam melaksanakan kegiatan pembelajarannya. Di Bekasi, dari tiga sekolah yang menjadi sasaran penelitian ini terdiri dari SDN VIII, SDN XIV dan SDN IX, serta terdiri dari 18 orang guru, memperoleh rata-rata nilai 66 dalam melaksanakan kegiatan pembelajaran dalam program pendidikan gratis.

\section{b. Dampak pada aspek partisipasi orang tua}

Partisipasi orang tua dapat berupa kegiatan sebagai berikut

1. Orang tua berpatisipasi terhadap keterserapan lulusan sekolah/madrasah unggulan

2. Orang tua berpartisipasi dalam mengembangkan lulusan yang memiliki kualitas akademik/non akademik yang dibanggakan

3. Orang tua berpartisipasi untuk mendorong pengakuan sekolah/madrasah jenjang selanjutnya terhadap lulusannya

4. Orang tua siswa berpartisipasi dalam pengembangan program akademik dan non akademik sekolah

5. Orang tua siswa berpartisipasi dalam merekomendasikan memilih sekolah/madrasah ini untuk peserta didik yang lain

6. Orang tua berpartisipasi dalam menunjukan keunggulan lulusan sekolah/ madrasah bagi peserta didik yang lain

Berdasarkan hasil penelitian terhadap kerangka ideal partisipasi aktif orang tua dalam pendidikan gratis pada sekolah atau madrasah di wilayah Jabodetabek. Di Jakarta, dari tiga sekolah yang menjadi sasaran penelitian ini yang terdiri dari MIN, dan dua SDN, serta terdiri dari 3 orang kepala sekolah, menginformasikan $68 \%$ berpatisipasi. Di Bogor, dari tiga sekolah yang terdiri dari SDN 01,02 dan 03, serta terdiri dari 3 orang kepala sekolah, menginformasikan bahwa partisipasinya adalah $66 \%$. Di Depok, dari tiga sekolah yang terdiri dari SDN 5, dua SDN 1 serta terdiri dari 3 orang kepala sekolah, memeperoleh angka partisipasi orang tua adalah $72 \%$ berpartisipasi. Di Tanggerang, dari tiga sekolah yang terdiri dari SDN 1, SDN VI dan SDN 02, serta terdiri dari 3 orang kepala sekolah, berpartisipasi dalam program pendidikan diksekolah adalah 73\%. Di Bekasi, dari tiga sekolah yang menjadi sasaran penelitian ini terdiri dari SDN VIII, SDN XIV dan SDN 
IX, serta terdiri dari 3 orang kepala sekolah, diperoleh infomrasi partisipasi orang adalah $75 \%$ berpatisipasi dalam kegiatan pendidikan yang diprogramkan sekolah.

Sebagaimana diketahui yang dijelaskan oleh Djibril (2011) mengungkapkan penjelasan Funco Tanipu, bahwa program pendidikan gratis di Indonesia sebenarnya juga memiliki beberapa dampak negatif dan dampak positif diantaranya sebagai berikut:

1. sekolah kurang dapat berkembang karena biaya operasional sekolah sangat tergantung dari bantuan pemerintah.

2. orangtua tidak dapat menuntut banyak karena merasa telah mendapatkan kemudahan melalui pendidikan gratis

3. terdapat peluang terjadinya penyelewengan dana jika kurangnya pengawasan yang ketat,

4. efek positif dari program pendidikan gratis, seperti meratanya pendidikan di Indonesia, meningkatkan mutu dan kualitas sumber daya manusia serta mengurangi tingkat pengangguran.

5. Pendidikan gratis yang bermutu juga perlu disesuaikan dengan kondisi setempat, , karena pendidikan membutuhkan biaya yang sangat mahal, namun peran masyarakat, pihak swasta, dan seluruh elemen yang ada, akan mampu mewujudkan keberhasilan pendidikan.

Disamping itu, Iradhati (2015) mengutip penjelasan AE Priyono Direktur Eksekutif Lembaga Penelitian, Pendidikan dan Penerangan Ekonomi dan Sosial (LP3ES), mengungkapkan, di Kabupaten Musi Banyuasin, Sumatera Selatan, dampak pendidikan gratis sebagai berikut:

1. membuat orangtua tidak peduli dan kurang bertanggung jawab terhadap pendidikan anaknya.

2. Orangtua tidak mau tahu anak-anak sekolah atau tidak.

3. Kecenderungan anak nakal, malas belajar, dan bolos.

4. Akibat ketidakpedulian orangtua tadi, pengawasan atas kelangsungan pendidikan anak-anak mereka pun mengendur. Pada akhirnya, ketidakpedulian itu juga memengaruhi keberlangsungan pendidikan anak-anak.

5. sikap guru menjadi apatis. Pasalnya, guru-guru kesulitan mengendalikan siswa yang menganggap guru tidak berhak mengintervensi dirinya mau masuk sekolah atau tidak.

Sementara itu, berdasarkan hasil penelitian dengan judul Model Pelaksanaan Pendidikan Gratis di Kabupaten/Kota dan Dampaknya di Tingkat Sekolah dan Orang tua oleh Nur Berlian VA. Temuannya: I) terdapat dua model pelaksanaan 
pendidikan "gratis", yaitu pembebasan dan pelarangan segala jenis pungutan oleh sekolah terhadap orangtua, dan subsidi biaya pendidikan dari pemerintah untuk meringankan beban orangtua, 2) tidak setnua kabupaten/kota memiliki \&tsar hukum yang kuat dalam melaksanakan program pendidikan "gratis"; 3) program pendidikan "gratis" cukup berpengaruh terhadap aspek pembelajaran dan manajemen sekolah, dan 4) pendidikan "gratis" berdampak positif dalam meringankan biaya pendidikan dan meningkatkan aktivitas belajar anak di sekolah dan di rumah.

\section{Kesimpulan}

Dari hasil penelitian diperoleh kesimpulan bahwa implementasi pendidikan gratis di Jabodetabek memenuhi standar mutu pendidikan baik dilihat dari input, proses, output, dan outcome pendidikan. Dilihat dari standar mutu pendidikan berbasis akreditasi, mutu pendidikan gratis di Jabodetak memenuhi standar mutu pendidikan dengan perolehan nilai A.

Model implementasi pendidikan gratis dari pendanaannya tergambar dalam tiga model pendidikan yaitu pembebasan segala jenis pungutan oleh sekolah terhadap orang tua, Pembebasan biaya operasional pendidikan terhadap orang tua kecuali biaya untuk kebutuhan pribadi seperti seragam sekolah dan pembiayaan operasional pendidikan dibebankan pada dana BOS (Biaya Operasional Sekolah).

Dampak implementasi pendidikan gratis berdasarkan pada mutu input, proses, output, dan outcome, serta mutu akreditasi juga model implementasi pendidikan gratis bagi orang tua, implementasi pendidikan gratis di Jabodetabek dengan standar mutunya tetap memiliki partisipasi dari masyarakat, memiliki kepuasan atas lulusannya, dan terbantu dari pembiyaan pendidikan secara gratis. Bagi guru berdasarkan pada perolehan data tentang mutu pendidikan gratis, guru melaksanakan pembelajaran belum memenuhi standar proses pembelajaran dengan optimal.

\section{Daftar Pustaka}

Arikunto, Suharsimi, 1993, Manajemen Penelitian, Jakarta, Rineka Cipta

Ashraf, Mohammad A. dan Yusnidah Ibrahim, (2009) Quality Education Management at private Universities in bangladesh: an exploratory study, Jurnal Pendidik dan Pendidikan, Jil. 24, 17-32, 2009

Asmuni, (2013) Konsep Mutu Dan Total Quality Manajement (TQM) Dalam Dunia Pendidikan, TA'DIB, Vol. XVIII, No. 01, Edisi Juni 2013

Badrudin, Syamsiah, Prof. Dr. Hj (2009) Menyorot PoliticalWill, PoliticalCommitment Dan Political Action Terhadap Pendidikan Gratis Dan Pembatasan Anak Usia Sekolah, Makalah 
Dany Mirawan (2010) Penjaminan Mutu Satuan Pendidikan Sebagai Upaya Pengendalian Mutu Pendidikan Secara Nasional dalam Otonomi Pendidikan, Jurnal: EDUCATIONIST Vol. IV No. 2 Juli 2010 ISSN : 1907 - 8838

Djibril, Muhammad (red) (2011) Dampak negatif pendidikan sekolah gratis, diakses http://www.republika.co.id/

Ekroman, Sri Soejatminah (2007) Quality Assurance Dalam Sistim Pendidikan Tinggi, Jakarta, Depdiknas

Gaspersz, Vincent (2003) Total Quality Management. Jakarta: Gramedia

Helba, Stephen (ed) (1995) Total Quality Management. Prentice Hall International Edition: LondonThe United States of Amerika

Iradhatie, Wurinanda (2015) Dampak Negatif Pendidikan gratis, http:// news.okezone. $\mathrm{com} / \mathrm{read} / 2015 / 12 / 15 / 65 / 1268077 /$ dampak-negatif-pendidikan-gratis

Kristianty, Theresia. (2005) Peningkatan Mutu Pendidikan Terpadu Cara Deming, Jurnal Pendidikan Penabur - No.04/ Th.IV /Juli 2005

Mu'ti, Abdul, dk. (2014) Pedoman Akreditasi Bermutu untuk Pendidikan Bermutu, Badan Akreditasi Nasional Sekolah/Madrasah: Jakarta, Kemdikbud

PP RI NO 19 tahun 2005 tentang Standar Nasional Pendidikan

Prayoga, 2014 Implementasi Program kartu Jakarta Pintar di Jakarta Barat, Skirpsi, Banten: Untirta

Sugiyono, 2004, Metode Penelitian Administrasi. Bandung, Alfabeta

Supriyanto, 2010. Analisis Implementasi Sekolah Gratis, Tesis. Depok, FISIP UI

Suti, Marus, 2011, Strategi Peningkatan Mutu Di Era Otonomi Pendidikan, Jurnal MEDTEK, Volume 3, Nomor 2, Oktober 2011

Wijaya, David (2008) Implementasi Manajemen Mutu Terpadu dalam Penyelenggaraan Pendidikan di Sekolah, Jurnal Pendidikan Penabur - No.10/Tahun ke-7/Juni 2008 